Associate Professor Özgül Polat ${ }^{1}$

Department of Preschool Education, Atatürk Faculty of Education

Marmara University, İstanbul, Turkey

Assistant Professor Nevra Atış-Akyol ${ }^{2}$

Department of Preschool Education, Faculty of Education

Sivas Cumhuriyet University, Sivas, Turkey
Original scientific paper

UDC: 371.315 .2

DOI: $10.5937 /$ IstrPed2102431P

\title{
MIND MAPPING AS A NEW METHOD THAT SUPPORTS READINESS FOR PRIMARY SCHOOL
}

\begin{abstract}
In the changing and developing world, the methods and approaches which promote learning experiences of individuals develop at the same pace. If such methods are integrated into the education system as an alternative to traditional teaching methods, it will enrich the learning experience for children and provide teachers with an opportunity to reach more children. As part of this, the research aims to use the mind mapping method to develop school readiness skills of preschoolers. This study was designed with a quantitative research procedure and was planned using a quasi-experimental design. The working group for the study was made up of 44 children, of which, 21 belong to the experimental group and 23 the control group. For the first step of the study, teachers were given mind mapping training and later the children in the experimental group were subjected to mind mapping applications in 22 themes (school, numbers, shapes, our healty, cooperation, emotions, nature...), comprising 7 large group and 15 individual mind mapping applications. The mind map theme of the week was covered every day in that week's program. As a result of the study, a significant difference in scores for school readiness skills between the experimental and control groups was revealed for all sub-dimensions in favour of the experimental group. The study indicates that the mind mapping technique applied with the children in the experimental group supports their readiness for primary school considerably.
\end{abstract}

Key words: early childhood education, mind mapping, preschool education, school readiness.

\section{Introduction}

Any investment in children in early childhood, which is the most fruitful period in terms of development and learning, enriches their academic and social life, enabling them to become successful individuals with a sense of meaning and responsibility within society. Findings of several studies show that social, emotional and academic development of children who receive preschool education are better than those of the children deprived of preschool education (Docket \& Perry, 2007; Lara-Cinisomo, Fuligni, \& Ritchie, 2008; West, Denton, \& Hausken, 2000; Zigler, Gilliam, \& Jones, 2006). Therefore, the support and education needed for children should be given in early childhood which is critical for their development. For any qualified preschool education to be offered to children, it needs to support learning skills which use methods and

\footnotetext{
1 polatozgul@gmail.com

²nevrarven@gmail.com
} 
techniques that will make learning easier. Thus, children's school readiness is supported.

Readiness for primary school refers to the cognitive, social-emotional and behavioural competences required of children to adapt to formal education (Lemelin et.al. 2007). Readiness for primary school covers the fields of physical welfare, motor development, social and emotional development, general knowledge and cognition (Kokkalia, Drigas, Economou, \& Roussos, 2019). In the same way that each country has its own preschool curriculum, each school offers support programs implemented based on the needs of that school. It is seen that several support programs which have been applied for readiness for primary school, particularly in recent years are usually divided into two: family support programs (Mathis \& Bierman, 2015; Landry et al., 2017; Padilla \& Ryan, 2018; Prendergast \& MacPhee, 2018; Wolf \& McCoy, 2019) and child support programs (Atteberry, Bassok, \& Wong, 2019; Brown, Garnett, VelazquezMartin, \& Mellor, 2018; Duncan, Schmitt, Burke, \& McClelland, 2017; Kybartas et al., 2019; Schmitt, McClelland, Tominey, \& Acock, 2015; Toran, Aydin, \& Etguer, 2019). Considering the structure of child support programs, there are studies such as the full-day program applications which increase the daily hours of the existing program to support the readiness of children for primary school (Atteberry, Bassok, \& Wong, 2019) or specially-designed school readiness programmes (Mercan-Uzun, \& Alat, 2015; Pears et al., 2014; Watts et al., 2018). Moreover, there are various studies that utilise current methods and techniques which are thought to strengthen the school readiness level of children. Such support programs are the preschool education practices enriched with comprehensive art education (Brown et.al., 2018), the programmes for the development of self-regulation skills (Duncan at.al. 2018; Schmitt et.al., 2015), physical activity programmes (Kybartas et.al., 2019) and extensive STEM applications (Toran, Aydin, \& Etguer, 2019). As with the current study, the findings which advocate that school readiness of children can be promoted through various programs and methods leads us to believe that it is feasible to employ mind mapping methods in this process. Children have different individual features and interests, hence diversification of the methods used in education raises the likelihood of reaching all children.

The use of mind mapping came about after the 1960 studies carried out by Tony Buzan, an English psychologist, mathematician and brain researcher (Buzan \& Buzan, 2009). The implementation of mind maps in education in the twenty first century gained momentum with the rise of multi-model educational mentality and technology and in doing so, they took their place in education as a method that served to improve the competences of the 21st Century as with technology, cooperation and visualization. A mind map is a diagram which resembles a picture rather than text, and when looked upon from above resembles a tree with its branches coming off the trunk in all directions with the use of keywords to simplify the information. This technique can be used as a learning tool, studying tool and application tool (Rustler, 2012). Mind maps represents a robust and unique method which activates all brain functions (words, imagination, numbers, causes, rhythm, images, lists, details, colours and spatial awareness) (Buzan, Dottino, \& Israel, 2012). Mind maps have been utilised in recent years in order to develop new ideas, remember existing knowledge easily, take notes, make correlations to understand a complex concept, improve memory, facilitate learning and achieve permanent learning (Buzan \& Buzan, 2015).

It is seen in several studies that mind mapping is used at different educational levels to promote the student development in various fields. For example, it is stated that mind mapping applied to students of the mathematics teaching department in Western University made positive contribution to education (Cendros \& Gadanidis, 2020). Additionally, mind mapping is employed frequently at primary and secondary schools. According to the analysis on the effects of mind mapping on memory improvement in learning (Irman, 2019), cognitive process skills (Indriani \& 
Mercuriani, 2019), problem solving skills (Sugiyanto, Masykuri, \& Muzzazinah, 2018), various mathematical skills (Mardiyah, Suhito, \& Safa'atullah, 2018), creative thinking and science education (Widiana \& Jampel, 2016) and internal motivation levels (Amin \& Hina, 2018), positive outcomes of mind mapping in education were revealed. Besides, numerous skills such as thinking and reasoning, determining possible causes, analysing, caution, memory, coordination, creativity, imagination, reading, writing, visualization, planning and application, and emotions are used simultaneously in mind mapping (Wen-Cheng, Chung-Chieh, \& Ying-Chien, 2010). It is seen that studies which target learning with children through the mind mapping method are generally for reading (Inayah, \& Argawati, 2019; Karolina, 2019; Khatimah, \& Rachman, 2018;) and writing skills (Dianto \& Basuni, 2015; Inayah, \& Argawati, 2019; Lastari \& Hadi, 2018; Sukma $\&$ Ria, 2018) in children of older ages. On the other hand, it was found out that mathematical and science skills of children increased with mind mapping applied during the preschool period. In a meta-analysis study which examined mind mapping studies about learning and teaching, it was stated that visualization tools have been popular in recent years and have had a positive effect on teaching and learning (Liu, Zhao, Ma, \& Bo, 2014). In light of this information, it is thought that readiness skills of children in primary school may rise by applying the mind mapping method.

In early childhood, which is defined as the magical years of life, mind mapping may give children skills that could lead them to success during their lives such as multidimensional thinking, problem solving, creativity, conceptualization, analysis, synthesis and cooperation. For this reason, it is vital to teach mind mapping which is an influential alternative technique that will provide children with the skills of alternative thinking, organising their ideas, generating idea networks and reflecting them, all of which will support their readiness for primary school. Thus, a permanent learning opportunity will arise for children. This research aims to analyse the school readiness level of children involved in mind mapping during a school year. Research question; "Does mind mapping have an effect on school readiness levels of 6-year-old children?"

\section{Method}

This research designed with a quantitative research procedure was conducted within a quasiexperimental design. Quasi-experimental designs are studies where the experimental group is identified randomly from within the group that already exists (Fraenkel, Wallen, \& Hyun, 2011). Furthermore, pre-test \& post-test trial techniques are utilised in this research. In this method, the experimental and control groups were subjected to pre-tests prior to the study. The application was then carried out with the experimental group only. Later, post-tests were implemented in both groups (Buyukozturk et al., 2012).

\subsection{Research Sample}

At the beginning of the study, children took part in pre-test applications and thus the similarity in the distribution of children's MSRP scores was determined and a class was chosen as the experimental group while another class was assigned as the control group. The working group for the study consisted of 44 children from a private preschool, of which 21 were part of the experimental group and 23 were part of the control group. Teachers of the preschool attended mind mapping training given by the researchers and expressed a desire to use mind mapping in their classes during the 2018-19 school year. Thereupon, under the guidance of the researchers, a plan was put into place in relation to the study for the teachers to provide the children with mind mapping skills and the relevant preschool was contacted. All families who were presented information regarding the research gave approval for their children to be part of the study group. 
All teachers participating in the study had a bachelor's degree, a minimum of 5 years teaching experience and were female. Of those that were in the working group, 9 girls and 12 boys made up the experimental group whereas the control group consisted of 12 girls and 11 boys. The mean age of the experimental group was 65.9 months and of the control group was 64.7 months.

\subsection{Data Collection Tool}

Marmara Scale of Readiness for Primary School (MSRP): MSRPwas developed by Polat-Unutkan (2003) to evaluate the primary school readiness of 60-78 month-old children in Turkey. This measuring tool had two forms: development and practice. In the practice form of the scale, the measurement was made based on performance of the children. The researcher applied the scale to the child via an illustrated test booklet in an environment which fully met test conditions. The form for this application was composed of 74 questions and the following 5 subdimensions: mathematical skills (47), science skills (14), sound studies (8), line studies (3) and mazes (2). The development form comprised of the sub-dimensions of mental-language development (74), social-emotional development (40), physical development (23) and self-care skills (16). It contained a total of 153 items to be filled in teacher of the child. As a result of the analyses made to determine the reliability of the measuring tool, cronbach alpha values of the sub-dimensions in the application were found between $r=.80-r=.96 p<.01$. It is understood that all reliability values attained were quite high (Polat-Unutkan, 2003).

\subsection{Mind Mapping Practices}

Before mind mapping studies were carried out, all teachers at the school were provided with training on mind mapping 4 weeks in the summer period and the application of the method was carried out 31 weeks in 2018 -2019 Education Period. Mind mapping applications started with large group studies in accordance with the themes determined.

2.3.1. Large Group Mind Mapping Studies: A total of 8 large group mind mapping studies were performed with the experimental group every 15 days during the autumn term. The themes/concepts that were chosen for this study, which aims to teach mind mapping skills, were chosen on the basis of things that were already present for children in the everyday life and on which they would have a great deal of thoughts. The themes specified collectively by teachers and researchers were "School", "Emotions", "Vehicles", "Nature (extinct and endangered animals, water, recycling, etc.)", "Seasons", "Self-Care", "Play and Activity", "Social Life". Figure 1 shows a large group mind map themed "Vehicles" which was carried out with the children.

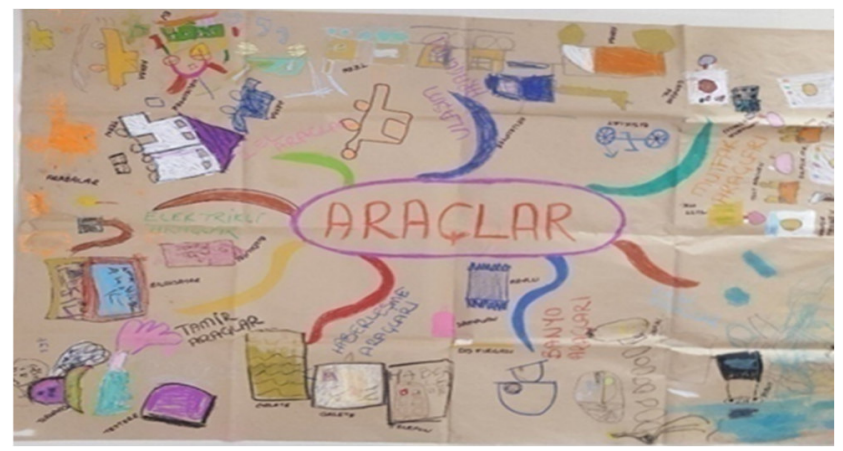

Figure 1. Example of a mind map made with a large group 
In accordance with the themes previously set by the teacher and research advisor, students in the experimental group were started the subject of "School" as part of the daily routine and the second week the mind map were done. In this way, the students were able to gain the knowledge needed to perform mind mapping in accordance with the relevant theme. As such, in order to create effective mind maps, children would be able to understand the logic behind mind maps and be given the opportunity to utilise collaboration and learning from your peers when creating mind maps. At the beginning of these studies, a large work space was created by combining at least 4 sheets of craft paper, on which the teacher would write the theme of the week within a circle in the middle of the sheet, using crayons. Children were encouraged to form the key words by themselves. After the main theme was written in the centre, guide lines were drawn from the circle representing branches of a tree coming out of the trunk, on which children were asked to place their initial ideas about the relevant theme. During the mind mapping sessions performed with the whole class who lied down in a relaxed environment accompanied by music, the children expressed and discussed their ideas on the related theme, shared them with each other and illustrated their decisions on the main branches. The teacher encouraged the children during this process and tried to explain the meaning of their drawings using the children's own wording. Moreover, the teacher provided guidance by helping them associate their pictures with the main branches and main theme.

2.3.1. Individual Mind Mapping Studies: In this period, children performed 15 mind mapping activities each of which was carried out once a week. Mind maps were about the following themes/concepts: "Colours", "Numbers", "Shapes", "Opposite Concepts", "Time”, "Sounds" (the words which begin with the same sound and end with the same sound, rhyming words), "Punctuation Marks", "Problem solving" (solving a problem in a photo), "Rules", "Cooperation, "Sports", "Our Health", "Sharing", "Measuring" and "Differences". Mind mapping sessions were generally carried out on Fridays, the last work day of the week with the aim of fallowing children to have had the time to develop the knowledge needed for the relevant theme. Children were left completely free during this process and their teacher helped them only in writing their ideas about their pictures. The individual mind maps themed "Time" and "Sharing" are shown as examples in Figure 2.

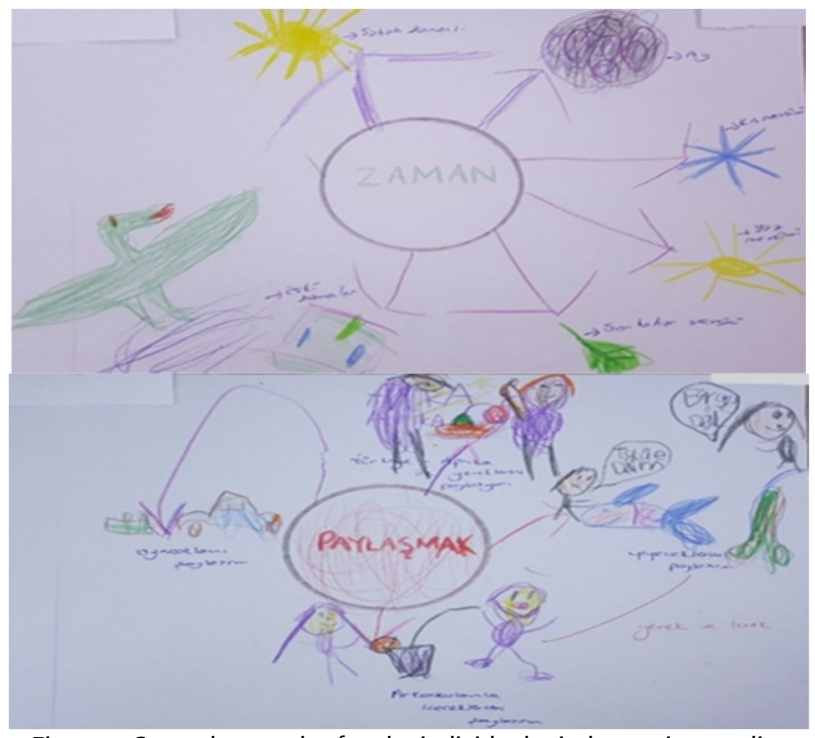

Figure 2. Several examples for the individual mind mapping studies 
Each child individually made mind maps while listening to music at a table or on floor in the class without influencing each other. For each one, a piece of A4 paper was placed horizontally, the weekly theme was written in its centre and encircled. While ensuring the reinforcement of basic emotions, knowledge, skills and behaviours that support children's readiness for primary school, the themes chosen by the teachers and researchers are ones that aim make them think, encourage them to group the information, give them the opportunity to determine their feelings and understand themselves through interesting themes and concepts.

In this way, the children who learned mind mapping during the school year applied mind mapping individually and each child carried out a total of 23 mind mapping activities, 8 as part of a larger group and 15 individual ones. Prior to individual mind mapping, various games and activities were carried out with the children in order to support their physical development, relaxation and concentration before carrying out the mind mapping activities.

It is thought that the learning of children will be promoted positively by means of the mind mapping method which enables their knowledge to be structured and managed, thus their readiness level for primary school will rise. On the other hand, the control group was subjected to the national curriculum and they was deprived only of the mind mapping studies.

\subsection{Ethical Consideration}

The researchers came together with school heads, teachers and families, informed them about the research process planned and answered any of their questions. A commitment was made to teachers and families that the information to be obtained as part of the research will be used for scientific purpose and the principle of confidentiality of information was highlighted. The research process started after written consent was obtained from teachers and the families who voluntarily permitted the participation of their children in the study. The control group was included in the mind mapping applications following the post-test procedures for equal opportunity.

\subsection{Data Analysis}

The number of participants in experimental and control groups were lower than 30 , so the Shapiro-Wilk test which is suggested for analysing the normality of data distribution was applied (McKillup, 2012). As a result of the Shapiro-Wilk tests carried out to determine whether or not the scores of the experimental and control groups obtained from the MSRP Practice Form and Development Form showed normal distribution during pre-tests and post-tests, it was revealed that in the pre-tests scores of the sub-dimensions other than sound, total practice and social-emotional development scores, and their total scores in the experimental group, do not show normal distribution $(\mathrm{p}<.05)$. It was found that in the post-tests the MSRP subdimensions and their total scores in both the experimental and control groups did not show normal distribution ( $p<.05)$. The MSRP Practice Form scores of experimental and control groups did not have normal distribution in the post-tests and the number of children in the experimental and control groups was lower than 30, therefore the Mann Whitney $U$ and Wilcoxon tests characterized as non-parametric difference tests were utilised for data analysis. The Mann Whitney $U$ test was used for the analysis of the pre-test scores of the experimental and control groups between themselves. Wilcoxon test was applied for comparative analysis of the pre-test and post-test scores. 


\section{Results}

Table 1. Pre-test results of the practice scores in experimental and control groups

\begin{tabular}{|c|c|c|c|c|c|c|c|}
\hline Sub-scale & Group & $\mathbf{N}$ & $\begin{array}{l}\text { Mean } \\
\text { Rank }\end{array}$ & $\begin{array}{l}\text { Sum of } \\
\text { Ranks }\end{array}$ & $\mathbf{U}$ & $\mathbf{z}$ & $p$ \\
\hline \multirow[t]{3}{*}{ math_score } & $\begin{array}{l}\text { Experimental } \\
\text { group }\end{array}$ & 21 & 23.40 & 491.50 & 222.500 & -.448 & 654 \\
\hline & Control group & 23 & 21.67 & 498.50 & & & \\
\hline & Total & 44 & & & & & \\
\hline \multirow[t]{3}{*}{ science_score } & $\begin{array}{l}\text { Experimental } \\
\text { group }\end{array}$ & 21 & 19.90 & 418.00 & 187.000 & -1.296 & 195 \\
\hline & Control group & 23 & 24.87 & 572.00 & & & \\
\hline & Total & 44 & & & & & \\
\hline \multirow[t]{3}{*}{ letter_sound_score } & $\begin{array}{l}\text { Experimental } \\
\text { group }\end{array}$ & 21 & 22.93 & 481.50 & 232.500 & -.216 & 829 \\
\hline & Control group & 23 & 22.11 & 508.50 & & & \\
\hline & Total & 44 & & & & & \\
\hline \multirow[t]{3}{*}{ line_score } & $\begin{array}{l}\text { Experimental } \\
\text { group }\end{array}$ & 21 & $25 \cdot 52$ & 536.00 & 178.000 & -1.769 & 077 \\
\hline & Control group & 23 & 19.74 & 454.00 & & & \\
\hline & Total & 44 & & & & & \\
\hline \multirow[t]{3}{*}{ maze_score } & $\begin{array}{l}\text { Experimental } \\
\text { group }\end{array}$ & 21 & 20.76 & 436.00 & 205.000 & -.979 & 327 \\
\hline & Control group & 23 & 24.09 & 554.00 & & & \\
\hline & Total & 44 & & & & & \\
\hline \multirow[t]{3}{*}{ practice_total_score } & $\begin{array}{l}\text { Experimental } \\
\text { group }\end{array}$ & 21 & 23.12 & 485.50 & 228.500 & -.306 & 760 \\
\hline & Control group & 23 & 21.93 & 504.50 & & & \\
\hline & Total & 44 & & & & & \\
\hline
\end{tabular}

In Table 1, it was detected that there is not any significant difference between mathematical $(U=222,500, p>.05)$, science $(U=187,000, p>.05)$, sound $(U=232,500, p>.05)$, line $(U=178,000$, $p>.05)$, maze $(U=205,000, p>05)$ and total practice scores $(U=228,500, p>.05)$ in the experimental and control groups.

Table 2. Pre-test results of the development scores in experimental and control groups

\begin{tabular}{|c|c|c|c|c|c|c|c|}
\hline Sub-scale & group & $\mathrm{N}$ & $\begin{array}{c}\text { Mean } \\
\text { Rank }\end{array}$ & $\begin{array}{c}\text { Sum of } \\
\text { Ranks }\end{array}$ & U & $\mathbf{z}$ & $p$ \\
\hline \multirow[t]{3}{*}{ mental_lan_pre } & $\begin{array}{l}\text { Experimentpre- } \\
\text { tests }\end{array}$ & 21 & 28.82 & 980.00 & 385.000 & -1.288 & 198 \\
\hline & Control pre-tests & 23 & 34.75 & 973.00 & & & \\
\hline & Total & 44 & & & & & \\
\hline \multirow[t]{3}{*}{ social_emot_pre } & $\begin{array}{l}\text { Experiment pre- } \\
\text { tests }\end{array}$ & 21 & 31.94 & 1086.00 & 461.000 & -.212 & 832 \\
\hline & Control pre-tests & 23 & 30.96 & 867.00 & & & \\
\hline & Total & 44 & & & & & \\
\hline \multirow[t]{3}{*}{ physical_pre } & $\begin{array}{l}\text { Experiment pre- } \\
\text { tests }\end{array}$ & 21 & 28.59 & 972.00 & 377.000 & -1.411 & 158 \\
\hline & Control pre-tests & 23 & 35.04 & 981.00 & & & \\
\hline & Total & 44 & & & & & \\
\hline \multirow[t]{3}{*}{ selfcare_pre } & $\begin{array}{l}\text { Experiment pre- } \\
\text { tests }\end{array}$ & 21 & 30.82 & 1048.00 & 453.000 & -.328 & 743 \\
\hline & Control pre-tests & 23 & 32.32 & 905.00 & & & \\
\hline & Total & 44 & & & & & \\
\hline
\end{tabular}




\begin{tabular}{|c|c|c|c|c|c|c|c|}
\hline \multirow[t]{3}{*}{ development_total_pre } & $\begin{array}{l}\text { Experiment pre- } \\
\text { tests }\end{array}$ & 21 & 28.44 & 967.00 & \multirow[t]{3}{*}{372.000} & \multirow[t]{3}{*}{-1.471} & \multirow[t]{3}{*}{141} \\
\hline & Control pre-tests & 23 & 35.21 & 986.00 & & & \\
\hline & Total & 44 & & & & & \\
\hline
\end{tabular}

In Table 2, it was found out that there is not any significant difference between mental-language $(U=385,000, p>.05)$, social-emotional $(U=461,000, p>.05)$, physical $(U=377,000, p>.05)$, self-care skills $(U=453,000, p>.05)$ and total development scores $(U=372,000, p>.05)$ in experimental and control groups.

Table 3. Pre-test and post test results of the practice scores in experimental group

\begin{tabular}{|c|c|c|c|c|c|c|}
\hline Sub-scale & & $\mathrm{N}$ & Mean Ra & $\mathrm{n}$ of Ranks & $\bar{z}$ & $p$ \\
\hline $\begin{array}{l}\text { math_score_post - } \\
\text { math_score_pre }\end{array}$ & $\begin{array}{l}\text { Negative Ranks } \\
\text { Positive Ranks } \\
\text { Ties } \\
\text { Total }\end{array}$ & $\begin{array}{c}0 \\
19 \\
2 \\
21\end{array}$ & $\begin{array}{c}00 \\
10.00\end{array}$ & $\begin{array}{c}00 \\
190.00\end{array}$ & -3.827 & $.000^{* *}$ \\
\hline $\begin{array}{l}\text { science_score_post - } \\
\text { science_score_pre }\end{array}$ & $\begin{array}{l}\text { Negative Ranks } \\
\text { Positive Ranks } \\
\text { Ties } \\
\text { Total }\end{array}$ & $\begin{array}{c}0 \\
18 \\
3 \\
21\end{array}$ & $\begin{array}{c}00 \\
9.50\end{array}$ & $\begin{array}{c}00 \\
171.00\end{array}$ & -3.745 & $.000^{* *}$ \\
\hline $\begin{array}{l}\text { letter_sound_score_post } \\
\text { - letter_sound_score_pre }\end{array}$ & $\begin{array}{l}\text { Negative Ranks } \\
\text { Positive Ranks } \\
\text { Ties } \\
\text { Total }\end{array}$ & $\begin{array}{c}0 \\
21 \\
0 \\
21\end{array}$ & $\begin{array}{c}00 \\
11.00\end{array}$ & $\begin{array}{c}000 \\
231.00\end{array}$ & -4.038 & $.000^{* *}$ \\
\hline $\begin{array}{l}\text { line_score_post - } \\
\text { line_score_pre }\end{array}$ & $\begin{array}{l}\text { Negative Ranks } \\
\text { Positive Ranks } \\
\text { Ties } \\
\text { Total }\end{array}$ & $\begin{array}{c}0 \\
20 \\
1 \\
21\end{array}$ & $\begin{array}{c}00 \\
10.50\end{array}$ & $\begin{array}{c}00 \\
210.00\end{array}$ & -4.008 & $.000^{* *}$ \\
\hline $\begin{array}{l}\text { maze_score_post - } \\
\text { maze_score_pre }\end{array}$ & $\begin{array}{l}\text { Negative Ranks } \\
\text { Positive Ranks } \\
\text { Ties } \\
\text { Total }\end{array}$ & $\begin{array}{c}1 \\
18 \\
2 \\
21\end{array}$ & $\begin{array}{l}8.00 \\
10.11\end{array}$ & $\begin{array}{c}8.00 \\
182.00\end{array}$ & -3.722 & $.000^{* *}$ \\
\hline $\begin{array}{l}\text { practice_total_score_pos } \\
\text { - practice_total_score_pre }\end{array}$ & $\begin{array}{l}\text { tNegative Ranks } \\
\text { ePositive Ranks } \\
\text { Ties } \\
\text { Total }\end{array}$ & $\begin{array}{c}0 \\
21 \\
0 \\
21\end{array}$ & $\begin{array}{c}00 \\
11.00\end{array}$ & $\begin{array}{c}00 \\
231.00\end{array}$ & -4.016 & $.000^{* *}$ \\
\hline
\end{tabular}

Med: Medians were reported:

In Table 3, the mathematical pre-test scores of the experimental group (Med=37) are significantly lower than its mathematical post-test scores (Med=47) $(z=-3.827, p<.05, r=.59)$. the science pre-test scores (Med=11) are significantly lower than the science post test scores $(M e d=14)(z=-3.745, p<.05, r=.57)$. Similarly, the sound pre-test scores (Med=3) are significantly lower than the sound post-test scores $(\mathrm{Med}=8)(z=-4.038, \mathrm{p}<.05, r=.62)$. The line pre-test scores (Med=1) are significantly lower than the line post-test scores $(M e d=2)(z=-4.008, p<.05, r=.61)$. The maze pre-test scores $(\mathrm{Med}=0)$ are significantly lower than the maze post-test scores $(M e d=2)(z=-3.722, p<.05, r=.57)$. As with the above findings, the practice pre-test scores of the experimental group $(\mathrm{Med}=52)$ are significantly lower than its practice post test scores $(M e d=71)$ $(z=-4.016, p<.05, r=.62)$.

$R$ values indicate the effect of the practice with regard to the MSRP Practice Form subdimensions and total practice score. The $\mathrm{R}$ values obtained here are equal to .50 or higher than .50 in all sub-dimension scores and total practice scores. This effect represents a high impact (Cohen, 1988; Field \& Hole, 2003; Thalheimer \& Cook, 2002). In other words, the application 
presented to the experimental group significantly affected their mathematical, science, sound, line, maze and total practice scores of the children.

Table 4. Pre-test and post test results of the development scores in experimental group

\begin{tabular}{|c|c|c|c|c|c|c|}
\hline & & $\mathbf{N}$ & $\begin{array}{l}\text { Mean } \\
\text { Rank }\end{array}$ & $\begin{array}{c}\text { Sum of } \\
\text { Ranks }\end{array}$ & $\mathbf{z}$ & $p$ \\
\hline \multirow{4}{*}{$\begin{array}{l}\text { mental_lan_post - } \\
\text { mental_lan_pre }\end{array}$} & Negative Ranks & 1 & 3.00 & 3.00 & -3.911 & $.000^{* *}$ \\
\hline & Positive Ranks & 20 & 11.40 & 228.00 & & \\
\hline & Ties & 0 & & & & \\
\hline & Total & 21 & & & & \\
\hline \multirow{4}{*}{$\begin{array}{l}\text { social_emo_post - } \\
\text { social_emo_pre }\end{array}$} & Negative Ranks & 2 & 3.50 & 7.00 & -3.774 & $.000^{* *}$ \\
\hline & Positive Ranks & 19 & 11.79 & 224.00 & & \\
\hline & Ties & 0 & & & & \\
\hline & Total & 21 & & & & \\
\hline \multirow{4}{*}{$\begin{array}{l}\text { physical_post - } \\
\text { physical_pre }\end{array}$} & Negative Ranks & 1 & 3.50 & 3.50 & -3.899 & $.000^{* *}$ \\
\hline & Positive Ranks & 20 & 11.38 & 227.50 & & \\
\hline & Ties & 0 & & & & \\
\hline & Total & 21 & & & & \\
\hline \multirow{4}{*}{$\begin{array}{l}\text { self-care_post - self- } \\
\text { care_pre }\end{array}$} & Negative Ranks & 1 & 2.00 & 2.00 & -3.950 & $.000^{* *}$ \\
\hline & Positive Ranks & 20 & 11.45 & 229.00 & & \\
\hline & Ties & 0 & & & & \\
\hline & Total & 21 & & & & \\
\hline \multirow{4}{*}{$\begin{array}{l}\text { development_total_post } \\
\text { - development_total_pre }\end{array}$} & Negative Ranks & 0 & 00 & 00 & -4.015 & $.000^{* *}$ \\
\hline & Positive Ranks & 21 & 11.00 & 231.00 & & \\
\hline & Ties & 0 & & & & \\
\hline & Total & 21 & & & & \\
\hline
\end{tabular}

Med: Medians were reported:

In Table 4, the mental-language pre-test scores of the experimental group (Med=175) are significantly lower than its mental-language post-test scores (Med=198) $(z=-3.911, p<.05, r=.60)$. The social-emotional pre-test scores $(\mathrm{Med}=80)$ are significantly lower than the social-emotional post-test scores (Med=104) ( $z=-3.774, p<.05, r=.58)$. Similarly, the physical development pre-test scores $(M e d=61)$ are significantly lower than the physical development post-test scores $(M e d=66)(z=-3.899, p<.05, r=.60)$. The self-care skills pre-test scores $(M e d=36)$ are significantly lower than the self-care skills post-test scores $($ Med=45) $(z=-3.950, p<.05, r=.60)$. As with the above findings, the development pre-test scores of the experimental group (Med=353) are significantly lower than its development post-test scores (Med=411) $(z=-4.015, p<.05, r=.62)$.

The $R$ values show the effect of the practice with regard to MSRP Development Form subdimensions and total practice score. The $\mathrm{R}$ values obtained here are equal to .50 or higher than .50 in all sub-dimension scores and total practice score. This affect represents a high impact (Cohen, 1988; Field \& Hole, 2003; Thalheimer \& Cook, 2002). Namely, the application presented to the experimental group significantly affected the development of the children.

Table 5. Pre-test and post-test results of the practice scores in control group

\begin{tabular}{llccccc}
\hline & & N & Mean Rank Sum of Ranks & z & p \\
\hline math_score_post - & Negative Ranks & 3 & 4.50 & 13.50 & -3.673 & $.000^{* *}$ \\
math_score_pre & Positive Ranks & 19 & 12.61 & 239.50 & & \\
& Ties & 1 & & & & \\
& Total & 23 & & & & $.000^{* *}$ \\
\hline science_score_post - & Negative Ranks & 0 & 00 & 00 & -3.569 & \\
science_score_pre & Positive Ranks & 16 & 8.50 & 136.00 & & \\
& Ties & 7 & & & & \\
& Total & 23 & & & & \\
& &
\end{tabular}




\begin{tabular}{|c|c|c|c|c|c|c|}
\hline $\begin{array}{l}\text { letter_sound_score_post } \\
\text { - letter_sound_score_pre }\end{array}$ & $\begin{array}{l}\text { Negative Ranks } \\
\text { Positive Ranks } \\
\text { Ties } \\
\text { Total } \\
\end{array}$ & $\begin{array}{c}3 \\
13 \\
7 \\
23\end{array}$ & $\begin{array}{l}3.33 \\
9.69\end{array}$ & $\begin{array}{c}10.00 \\
126.00\end{array}$ & -3.055 & $.002^{* * *}$ \\
\hline $\begin{array}{l}\text { line_score_post - } \\
\text { line_score_pre }\end{array}$ & $\begin{array}{l}\text { Negative Ranks } \\
\text { Positive Ranks } \\
\text { Ties } \\
\text { Total } \\
\end{array}$ & $\begin{array}{c}6 \\
0 \\
17 \\
23 \\
\end{array}$ & $\begin{array}{c}3.50 \\
00\end{array}$ & $\begin{array}{c}21.00 \\
00\end{array}$ & -2.449 & $.014^{*}$ \\
\hline $\begin{array}{l}\text { maze_score_post - } \\
\text { maze_score_pre }\end{array}$ & $\begin{array}{l}\text { Negative Ranks } \\
\text { Positive Ranks } \\
\text { Ties } \\
\text { Total } \\
\end{array}$ & $\begin{array}{r}3 \\
7 \\
13 \\
23 \\
\end{array}$ & $\begin{array}{l}3.00 \\
6.57\end{array}$ & $\begin{array}{c}9.00 \\
46.00\end{array}$ & -1.937 & 053 \\
\hline $\begin{array}{l}\text { practice_total_score_postl } \\
\text { - practice_total_score_pref }\end{array}$ & $\begin{array}{l}\text { Negative Ranks } \\
\text { Positive Ranks } \\
\text { Ties } \\
\text { Total }\end{array}$ & $\begin{array}{c}2 \\
20 \\
1 \\
23\end{array}$ & $\begin{array}{c}2.50 \\
12.40\end{array}$ & $\begin{array}{c}5.00 \\
248.00\end{array}$ & -3.949 & $.000^{* *}$ \\
\hline
\end{tabular}

Med: Medians were reported:

In Table 5, the mathematical pre-test scores of the control group (Med=35) are significantly lower than the mathematical post-test scores $(M e d=46)(z=-3,673 p<.05, r=.54)$ The science pretest scores $(M e d=12)$ are significantly lower than the science post-test scores (Med=14) $(z=-$ $3.569, p<.05, r=.52)$. Similarly, sound pre-test scores $(\mathrm{Med}=3)$ are significantly lower than sound post test scores $(M e d=4)(z=-3,055, p<.05, r=.45)$. As with these findings, the total practice pretest scores of the control group (Med $=51)$ are significantly lower than its practice post-test scores $($ Med=64) $(z=-3.949, p<.05, r=.58)$. In contrast, line pre-test scores of the control group (Med=.00) are significantly higher than its line post test scores (Med=.00) $(z=-2.449 p<.05$, $r=.36)$ Any significant difference between maze pre-test scores (Med=1) and post test scores (Med=1) was not found $(z=-1.937, p>.05, r=.28)$. Contrary to these findings, line skills of the children in control group differed in favour of the pre-test whereas their maze skills did not differ.

The $R$ values show the effect of the national curriculum applied to the children in the control group with regards to the mathematical, science and sound sub-dimensions of the MSRP Practice Form and total practice score. The effect quantities found are over .40 and .50 This affect represents a high impact (Cohen, 1988; Field \& Hole, 2003; Thalheimer \& Cook, 2002). In other words, the national curriculum offered to the control group influenced their mathematical, science, sound and total practice scores considerably.

Table 6. Pre-test and post-test results of the development scores in the control group

\begin{tabular}{|c|c|c|c|c|c|c|}
\hline & & $\mathrm{N}$ & $\begin{array}{c}\text { Mean } \\
\text { Rank }\end{array}$ & $\begin{array}{c}\text { Sum of } \\
\text { Ranks }\end{array}$ & z & $p$ \\
\hline \multirow[t]{4}{*}{$\begin{array}{l}\text { mental_lan_post - } \\
\text { mental_lan_pre }\end{array}$} & $\begin{array}{l}\text { Negative } \\
\text { Ranks }\end{array}$ & 4 & 10.00 & 40.00 & -2.625 & $.009^{* \star}$ \\
\hline & $\begin{array}{l}\text { Positive } \\
\text { Ranks }\end{array}$ & 17 & 11.24 & 191.00 & & \\
\hline & Ties & 2 & & & & \\
\hline & Total & 23 & & & & \\
\hline \multirow[t]{4}{*}{$\begin{array}{l}\text { social_emo_post - } \\
\text { social_emo_pre }\end{array}$} & $\begin{array}{l}\text { Negative } \\
\text { Ranks }\end{array}$ & 7 & 5.29 & 37.00 & -3.074 & $.002^{* *}$ \\
\hline & $\begin{array}{l}\text { Positive } \\
\text { Ranks }\end{array}$ & 16 & 14.94 & 239.00 & & \\
\hline & Ties & 0 & & & & \\
\hline & Total & 23 & & & & \\
\hline
\end{tabular}




\begin{tabular}{|c|c|c|c|c|c|c|}
\hline \multirow[t]{4}{*}{$\begin{array}{l}\text { physical_post - } \\
\text { physical_pre }\end{array}$} & $\begin{array}{l}\text { Negative } \\
\text { Ranks }\end{array}$ & 0 & 00 & 00 & -3.637 & $.000^{* *}$ \\
\hline & $\begin{array}{l}\text { Positive } \\
\text { Ranks }\end{array}$ & 17 & 9.00 & 153.00 & & \\
\hline & Ties & 6 & & & & \\
\hline & Total & 23 & & & & \\
\hline \multirow[t]{4}{*}{$\begin{array}{l}\text { self-care_post - self- } \\
\text { care_pre }\end{array}$} & $\begin{array}{l}\text { Negative } \\
\text { Ranks }\end{array}$ & 11 & 9.59 & 105.50 & -.019 & 985 \\
\hline & $\begin{array}{l}\text { Positive } \\
\text { Ranks }\end{array}$ & 9 & 11.61 & 104.50 & & \\
\hline & Ties & 3 & & & & \\
\hline & Total & 23 & & & & \\
\hline \multirow[t]{4}{*}{$\begin{array}{l}\text { development_total_post } \\
\text { - development_total_pre }\end{array}$} & $\begin{array}{l}\text { Negative } \\
\text { Ranks }\end{array}$ & 5 & 7.00 & 35.00 & -3.133 & $.002^{* *}$ \\
\hline & $\begin{array}{l}\text { Positive } \\
\text { Ranks }\end{array}$ & 18 & 13.39 & 241.00 & & \\
\hline & Ties & 0 & & & & \\
\hline & Total & 23 & & & & \\
\hline
\end{tabular}

Med: Medians were reported:

In Table 6, the mental-language development pre-test scores of the control group (Med=184) are significantly lower than its mental-language post test scores (Med=198) $(z=-2.625, p<.05$, $r=.38$ ). The social-emotional development pre-test scores (Med=93) are significantly lower than social-emotional development post test scores $(\mathrm{Med}=98)(z=-3,074, p<.05, r=.45)$. Similarly, the physical development pre-test scores $(M e d=60)$ are significantly lower than the physical development post-test scores $(\mathrm{Med}=6)(z=-3.637, \mathrm{p}<.05, r=.53)$. As with these findings, the total development pre-test scores of the control group ( $\mathrm{Med}=393)$ are significantly lower than its total development post-test scores $(M e d=400)(z=-3.133, p<.05, r=.46)$. On the contrary, there was no significant difference between the self-care skills scores of the control group ( $M e d=37)$ and its post test scores (Med=37) $(z=-.019, p>.05)$.

The R values show the effect of the MNE (the Ministry of National Education) curriculum applied to the children in the control group with regard to mathematical, science and sound subdimensions of MSRP Practice Form and total practice score. The effect quantities found are over .38 and .50 This affect represents a high impact (Cohen, 1988; Field \& Hole, 2003; Thalheimer \& Cook, 2002). In other words, the national curriculum offered to control group affected the development of children.

Table 7. Post-test results of the practice scores in the Experimental and Control groups

\begin{tabular}{|c|c|c|c|c|c|c|c|}
\hline \multirow{2}{*}{ math_score } & \multirow{2}{*}{$\begin{array}{l}\text { Group } \\
\text { Experimental } \\
\text { group } \\
\text { Control group } \\
\text { Total } \\
\end{array}$} & $\frac{\mathbf{N}}{21}$ & \multicolumn{2}{|c|}{ Mean Rank Sum of Ranks } & \multirow{2}{*}{$\frac{U}{134.000}$} & \multirow{2}{*}{$\frac{z}{-2.613}$} & \multirow{2}{*}{$\frac{p}{.009^{* *}}$} \\
\hline & & $\begin{array}{l}21 \\
23 \\
44\end{array}$ & $\begin{array}{l}27.62 \\
17.83\end{array}$ & $\begin{array}{l}580.00 \\
410.00\end{array}$ & & & \\
\hline science_score & $\begin{array}{l}\text { Experimental } \\
\text { group } \\
\text { Control group } \\
\text { Total } \\
\end{array}$ & $\begin{array}{l}23 \\
44 \\
\end{array}$ & $\begin{array}{l}25.71 \\
19.57\end{array}$ & $\begin{array}{l}540.00 \\
450.00\end{array}$ & 174.000 & -2.030 & $.042^{*}$ \\
\hline letter_sound_score & $\begin{array}{l}\text { Experimental } \\
\text { group } \\
\text { Control group } \\
\text { Total }\end{array}$ & $\begin{array}{l}23 \\
44 \\
\end{array}$ & $\begin{array}{l}33.36 \\
12.59\end{array}$ & $\begin{array}{l}700.50 \\
289.50\end{array}$ & 13.500 & -5.509 & $.000^{* *}$ \\
\hline line_score & $\begin{array}{l}\text { Experimental } \\
\text { group }\end{array}$ & 21 & 34.00 & 714.00 & 000 & -6.309 & $.000^{* *}$ \\
\hline
\end{tabular}




\begin{tabular}{|c|c|c|c|c|c|c|c|}
\hline & $\begin{array}{l}\text { Control group } \\
\text { Total }\end{array}$ & $\begin{array}{l}23 \\
44\end{array}$ & 12.00 & 276.00 & & & \\
\hline \multirow[t]{3}{*}{$\overline{\text { maze_score }}$} & $\begin{array}{l}\text { Experimental } \\
\text { group }\end{array}$ & 21 & 26.50 & 556.50 & 157.500 & -2.100 & $.036^{*}$ \\
\hline & Control group & 23 & 18.85 & 433.50 & & & \\
\hline & Total & 44 & & & & & \\
\hline \multirow[t]{3}{*}{ practice_total_score } & $\begin{array}{l}\text { Experimental } \\
\text { group }\end{array}$ & 21 & 31.69 & 665.50 & 48.500 & -4.562 & $.000^{* *}$ \\
\hline & Control group & 23 & 14.11 & 324.50 & & & \\
\hline & Total & 44 & & & & & \\
\hline
\end{tabular}

In Table 7, it was revealed that the mathematical scores showed significant differences based on the variable of being in the experimental and control groups $(U=134.000, p<.05, r=.39)$. The mean ranks of the experimental group and the control group corresponded to 27.62 months and 17.83 , respectively. With respect to the mean ranks, the significant difference is in favour of experimental group. A significant difference between science scores of the experimental and control groups $(U=174.000, p<.05, r=.30)$ was determined. The mean ranks of the experimental group and control group corresponded to 25.71 months and 19.57, respectively. With respect to the mean ranks, the significant difference is in favour of the experimental group. Moreover, it was found that the sound scores of the experimental and control groups indicated significant differences $(U=13.500, p<.05, r=.83)$. The mean ranks of the experimental group and control group corresponded to 33.36 months and 12.59 , respectively. With respect to the mean ranks, the significant difference is in favour of the experimental group. It was revealed that the line scores of the experimental and control groups differ significantly $(U=.000, p<.05, r=.95)$. Mean ranks of the experimental group and control group corresponded to 34.00 months and 12.00, respectively. With respect to the mean ranks, the significant difference is in favour of the experimental group. Similarly, a significant difference in maze scores of the experimental and control groups was found $(U=157.500, p<.05, r=.31)$. The mean ranks of the experimental group and control group corresponded to 26.50 months and 18.85 , respectively. With respect to the mean ranks, the significant difference is in favour of the experimental group. Furthermore, it was detected that the total practice scores differed significantly $(U=48,500, p<.05, r=.68)$. The mean ranks of the experimental group and control group corresponded to 31.69 months and 14.11 , respectively. With respect to the mean ranks, the significant difference is in favour of the experimental group.

When effect quantities are analysed, it is seen that the highest impact wason line, sound and total practice scores whereas the effect on maze scores was moderate (Cohen, 1988: 22-27; Field and Hole, 2003: 153; Thalheimer and Cook, 2002). In other words, the mind mapping technique applied to the children in the experimental group influenced school readiness skills of children considerably.

Table 8. Post-test results of the development scores in Experimental and Control groups

\begin{tabular}{llrrrrrr}
\hline & Group & N & $\begin{array}{c}\text { Mean } \\
\text { Rank }\end{array}$ & $\begin{array}{c}\text { Sum of } \\
\text { Ranks }\end{array}$ & U & Z & P \\
\hline mental_lan_post & experimental & 21 & 33.25 & 931.00 & 259.000 & -2.182 & $.029^{*}$ \\
& group & 23 & 23.75 & 665.00 & & & \\
& control group & 44 & & & & & \\
& Total & 21 & 33.80 & 946.50 & 243.500 & -2.438 & $.015^{*}$ \\
& experimental & & & & & \\
& group & 23 & 23.20 & 649.50 & & & \\
& control group & 44 & & & & & \\
& Total & & & &
\end{tabular}




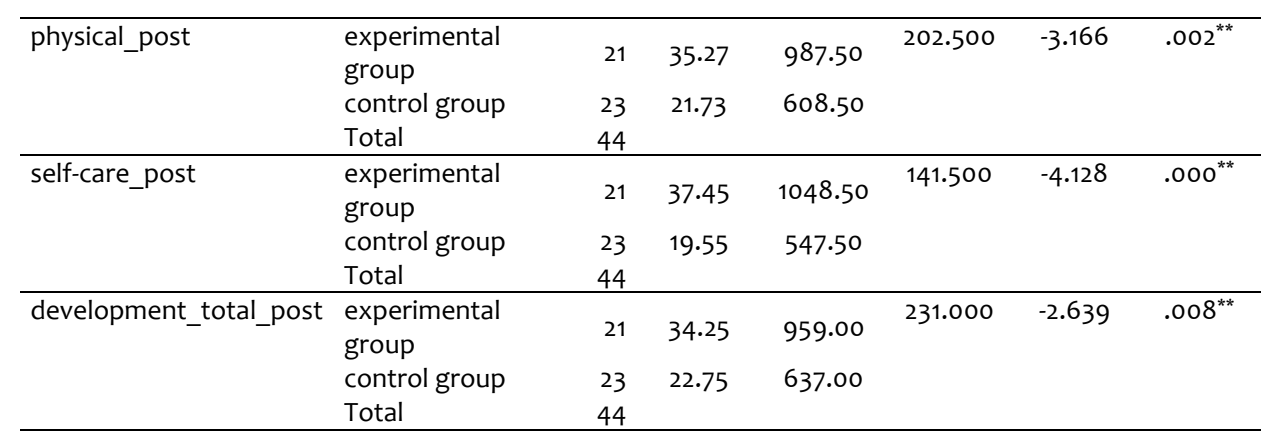

In Table 8, it was revealed that the mental-language development scores showed significant differences based on the variable of being in the experimental and control group ( $U=259.000$, $\mathrm{p}<.05, \mathrm{r}=.32$ ). The mean ranks of the experimental group and control group corresponded to 33.25 months and 23.75 , respectively. With respect to the mean ranks, the significant difference is in favour of experimental group. A significant difference between the social-emotional scores of the experimental and control groups $(\mathrm{U}=243.500, \mathrm{p}<.05, \mathrm{r}=.36)$ was determined. The mean ranks of the experimental group and control group corresponded to 33.80 months and 23.20, respectively. With respect to the mean ranks, the significant difference is in favour of the experimental group. Moreover, it was found that the physical development scores of the experimental and control groups indicated significant differences $(U=202.500, p<.05, r=.47)$. The mean ranks of the experimental group and control group corresponded to 35.27 months and 21.73, respectively. With respect to the mean ranks, the significant difference is in favour of the experimental group. Moreover, it was revealed that the self-care scores of the experimental and control groups differ significantly $(U=.141 .500, p<.05, r=.62)$. The mean ranks of the experimental group and control group corresponded to 37.45 months and 19.55 , respectively. With respect to the mean ranks, the significant difference is in favour of the experimental group. Furthermore, it was detected that the total development scores differ significantly $(U=231.000, p<.05, r=.39)$. Mean ranks of the experimental group and control group corresponded to 34.25 months and 22.75 , respectively. With respect to the mean ranks, the significant difference is in favour of experimental group.

When effect quantities are examined, it is seen that the highest impact formed on self-care skills and physical development scores whereas the effect on other development fields was moderate (Cohen, 1988: 22-27; Field and Hole, 2003: 153; Thalheimer and Cook, 2002). In other words, the mind map technique applied to the children in the experimental group influenced school readiness skills of the children considerably.

\section{Discussion, Conclusion, Recommendations}

In the study, the research question was examined which is "does mind mapping have an effect on school readiness levels of 6-year-old children". Analysis of each sub-dimension of the scale used in the research was carried out and the results were evaluated. It is seen that the mathematical, science, sound, line, maze and total practice form scores as well as the mindlanguage development, social-emotional development, physical development, self-care skills and total development form scores went up dramatically with mind mapping applications applied to the experimental group. The national curriculum implemented by the control group affected the mathematical, science, sound and total practice form scores and mind-language development, social-emotional development, physical development and total development form scores considerably. However, the line skills of the children in the control group differed 
in favour the pre-test scores whereas their maze and self-care skills did not differ significantly. In general, the increase in primary school readiness levels of the children both in the experimental group and control group is considered as an expected result of formal education within that seven months. Additionally, it is thought that self-care skills and maze skills did not present any significant development in control group, and line skills deteriorated due to insufficient practices which support these fields such as small muscle development.

As a consequence of the study, it is seen, considering the post-test results for the experimental and control groups that there is a significant difference in all sub-dimensions and both total practice form and development form scores in favour of the experimental group, and that their impact levels are quite high. For this reason, it was found out that the mind mapping technique implemented with the experimental group influenced school readiness skills of children positively and considerably. In literature, various studies which were conducted with the school preparation programs especially designed to develop school readiness skills of children, and achieved effective results are found (Karakas, 2015; Loniganve et.al., 2015; Pears et al., 2014; Sonmez, 2013; Uzun, 2015; Watts et al., 2018). Furthermore, there are several studies in literature which are similar to this research and promote school readiness skills of children with different programs or methods that were not exclusively designed as school preparation program. For example, the effect of narrative-based education (Ozsari, 2017), integration of art practices (Brown et al., 2018), education of self-regulation skills (Duncan et al., 2017; Schmitt et al., 2015), montessori method (Yildirim, 2019) and project approach-based education (DizmanOzaslan, 2010) on school readiness skills of children are seen. However, literature does not contain any study that scrutinizes the development of pre-schooler's school readiness skills by using mind maps.

Despite the unavailability of such above-mentioned studies in literature, there are numerous studies which utilise mind mapping to promote sub-dimensions of school readiness skills in parallel with the finding of the research. These researches can be categorised as follows: the contribution of mind mapping to the science learning of children (Balim, 2013; Evrekli \& Balim, 2010; Gagic, Skuban, Radulovic, Stojanovic, \& Gajic, 2019; Gomleksiz \& Fidan, 2013), the contribution of mind mapping to the learning of social sciences (Parikh, 2016), the contribution of mind mapping to mathematical learning (Brinkmann, 2003; Mardiyah et al., 2018), the contribution of mind mapping to reading skills (Inayah, \& Argawati, 2019; Karolina, 2019; Khatimah, \& Rachman, 2018), the contribution of mind mapping to writing skills (Dianto \& Basuni, 2015; Inayah, \& Argawati, 2019; Lastari \& Hadi, 2018; Sukma, \& Ria, 2018;), the contribution of mind mapping to listening and language development (Koster, Wilt, Kruistum, \& Veen, 2017) and the contribution of mind mapping to group studies (Luke, Lloyd, Boyd, \& Den Exter, 2014). This study contains similar research findings which indicate that mathematical, science, sound, line, maze, mental-language development and social-emotional development addressed as sub-dimensions of school readiness are supported with mind mapping applications. This outcome attained is regarded as an expected result, considering the features and benefits of mind mapping. It is known that the cognitive skills such as focusing, improvement of memory, creative thinking, relating, problem solving and analysing are all used with mind mapping applications (Buzan \& Buzan, 2015). In addition, mind mapping contributes to the social-emotional development of children especially at the stages of large group practices such as listening, expressing and defending one's own opinion, discussing all opinions and shared decision making. Moreover, children convey their opinions and knowledge through mind mapping applications by using various methods on paper such as lines, figures, pictures and diagrams, and even colouring these images as they wish. In this way, mind mapping makes children develop their learning and cognitive skills as well as fine motor skills, thereby enabling them to improve self-care skills such as zipping up, buttoning etc. In the evaluation of the result 
that mind mapping practices affect school readiness of children, the following point should be taken into consideration, that of the fact that the themes/concepts chosen were ones that would support school readiness. Integrative aspects of the national curriculum implemented at school and the availability of plays and activities, self-care skills, sports and health among the mind mapping themes/concepts promote the readiness in physical development and self-care sub-dimensions. Furthermore, it is thought that the games and dynamic activities performed by child before starting mind mapping, and personal cleaning and care regularly applied after mind mapping may help to raise the physical development and self-care skills of the child.

One of the most important points which explain the effect of mind mapping applications on school readiness of children is the positive influence of mind mapping on attention and motivation. Children should first focus on their attention levels and motivation on the performed activity in order to gain all skills and knowledge needed in the fields of development and learning. As one of the most fundamental conditions for learning, motivation contributes to effective learning of children (Akbaba, 2006). Therefore, attention and motivation are vital for success and adaptation, particularly in the preschool period (Huang \& LingLay, 2017). In a study which analyses the effect of mind maps on regulating attention deficit of pre-schoolers, a positive change in focusing of attention in favour of the experimental group was revealed (Daghistan, 2016). Another study conducted with undergraduates reported that the motivation of the students was increased with mind mapping (Jones, Ruff, Snyder, Petrich, \& Koonce, 2012). Similarly, it is shown in a study which examines the influence of mind mapping on management and coding of information, that mind maps affect both information management and the internal and external motivations of individuals (Pratami, Puspita, \& Hadining, 2017).

In summary, it is seen that the mind mapping applications carried out with 60-72month-old preschoolers as part of the study affected their school readiness skills considerably. During the research process, teachers were first provided with training on the use of mind mapping techniques in the preschool period, and then they performed mind mapping with the children in the experimental group. The study gave both teachers and children the opportunity to apply a new method. Thus, both teachers and children learned and applied this influential method which activates all brain functions such as imagination, cause and effect relationships, pictures, lists, details, colours and spatial awareness, with mind maps that enable them to diversify the traditional educational practices (Buzan, Dottino, \& Israel, 2012). In addition, thanks to mind mapping, teachers became aware of a different teaching method to reach those children who did not show adequate interest in the activities previously (Nesbit \& Adesope, 2006).

\subsection{Limitations}

There was no sufficient time for follow-up tests after the completion of the application, so follow-up test could not be performed. Numerous positive feedbacks were given to researchers in regards to the training provided to teachers. However, data was not collected from teachers systematically, so these contributing feedbacks could not be included in the research.

\subsection{Suggestions}

As is understood from the study results, it is seen that mind mapping applications support the primary school readiness skills of children. For this reason, it is important to use mind mapping practices regularly in the preschool period and to give teachers training on this subject. In the experimental studies carried out with mind mapping procedurally, an early start in terms of the initial training and applications is suggested to organize planning in a way that follow-up test 
can be performed. Additionally, it is recommended that mind mapping applications can be performed with the children of different ages who develop differently.

\section{References:}

Akbaba, S. (2006). Egitimde motivasyon. Ataturk Universitesi Kazım Karabekir Egitim Fakultesi Dergisi, 13, 343-361.

Amin, M., \& Hina, Q. A. (2018). Effect of mind mapping technique on student intrinsic motivation at higher education level. Journal of Research, 12(2), 296-313.

Atteberry, A., Bassok, D., \& Wong, V. C. (2019). The effects of full-day prekindergarten: experimental evidence of impacts on children's school readiness. Educational Evaluation and Policy Analysis, 41(4), 537-562. https://doi.org/10.3102/0162373719872197.

Balim, A. G. (2013). The effect of mind-mapping applications on upper primary students' success and inquiry-learning skills in science and environment education. International Research in Geographical and Environmental Education, 22(4), 337-352. https://doi.org/10.1080/10382046.2013.826543

Brinkmann, A. (2003). Graphical knowledge display - mindmapping and concept mapping as efficient tools in mathematics education. Mathematics Education Review, 16, 35-48.

Brown, E.D., Garnett, M.L. Velazquez-Martin, B.M. \& Mellor, T.J. (2018). The art of Head Start: Intensive arts integration associated with advantage in school readiness for economically disadvantaged children, Early Childhood Research Quarterly, 45, 204-214. https://doi.org/10.1016/j.ecresq.2017.12.002

Buzan, T., \& Buzan, B. (2009). The mind map book: Unlock your creativity, boost your memory, change your life. Pearson.

Buzan, T., \& Buzan, B. (2015) Zihin haritaları. (Cev. G. Tercanli). Alfa.

Buzan, T., Dottino, T., \& Israel, R. (2012). Akılli lider. (Cev. Serdar Ucar). Alfa.

Buyukozturk, S., Kilic-Cakmak, E., Akgun, O., Karadeniz, S., \& Demirel, F. (2012). Bilimsel arastırma yontemleri (12. Baski). Pegem akademi.

CendrosAraujo, R.,Gadanidis, G.(2020). Online collaborative mind mapping in a mathematics teacher education program: a study on student interaction and knowledge construction. ZDM MathematicsEducation. 52, 943-958 https://doi.org/10.1007/s11858019-01125-W

Cohen, J. C. (1988). Statistical power analysis for the behavioral sciences (2nd Ed.). Lawrence Earlbaum Associates.

Daghistan, B. I. A. M. (2016). Mind Maps to Modify Lack of Attention among Saudi Kindergarten Children. International Education Studies, 9(4), 245-256. http://dx.doi.org/10.5539/ies.vgn4p245

Dianto, R., \& Basuni, M. (2015). The effectıveness of usıng mind mappıng technıque toward the students'achievement in writing descriptive text. Jurnal Bahasa Lingua Scientia, 7(2), 165-172.

Dizman-Ozaslan, H., (2010). Proje yaklasımina dayali egitimin anaiınifina devam eden cocuklarin okul olgunluguna etkisinin incelenmesi. (Yayinlanmamıs Doktora Tezi), Ankara Universitesi Fen Bilimleri Enstitusu, Ankara.

Dockett, S., \& Perry, B. (2007). Transitions to school: Perceptions, expectations, experiences. UNSW Press.

Duncan, R.J.,Schmitt, S.A., Burke, M., \&McClelland, M.M. (2018) Combining a kindergarten readiness summer program with a self-regulation intervention improves schoolreadiness, Early Childhood Research Quarterly 42, 291-300. 


\section{https://doi.org/10.1016/j.ecresq.2017.10.012}

Essa, E.L. (2003). Introduction to Early Childhood Education. (3rded.). Delmar Learning.

Evrekli, E.,\& Balim, A. G. (2010). Fen ve teknoloji ogretiminde zihin haritasi ve kavram karikaturu kullaniminin ogrencilerin akademik basarilarina ve sorgulayici ogrenme becerileri algilarina etkisi. Bati Anadolu Egitim Bilimleri Dergisi, 1(2), 76-98.

Field, A.,\& Hole, G. (2003). How to design and report experiments. SAGE.

Fraenkel, J. R.,Wallen, N. E., \& Hyun, H. H. (2011). How to design and evaluate research in education. McGraw-Hill Humanities/Social Sciences/Languges.

Gagic, Z. Z.,Skuban, S. J., Radulovic, B. N., Stojanovic, M. M., \&Gajic, O. (2019). The Implementation Of MindMaps In Teaching Physics: Educational Efficiency And Students' Involvement. Journal of Baltic Science Education, 18. 117-131. https://doi.org/ $10.33225 / \mathrm{jbse} / 19.18 .17$

Gomleksiz, M. N.,\& Fidan, E. K. (2013). Fen ve teknoloji dersinde bilgisayar destekli zihin haritasi tekniginin ogrencilerin akademik basarisina, tutumlarina ve kaliciliga etkisi. Gaziantep University Journal of Social Sciences, 12(3). 403-426

Huang, S. Y \& LingLay, K. (2017). Mastery motivation in infancy and early childhood: the consistency and variation of its stability and predictability of general competence. Hungarian Educational Research Journal, 7(2), 15-31.

Inayah, R., \& Argawati, N. O. (2019). Nurturing students'writing narrative interest through mind mapping and cooperative integrated reading and writing. Indonesian EFL Journal, 5(2), 121-130. https://doi.org/10.25134/iefljv5i2.1781.

Indriani, D., \& Mercuriani, I. S. (2019). Experiential learning model with mind mapping on fungi: how to improve science process skills?. Biosfer: Jurnal Pendidikan Biologi, 12(2), 223237. https://doi.org/10.21009/biosferjpb.v12n2.223-237

Irman, I. (2019). The effectiveness of mind mapping techniques in counseling of enhancement ability memory students in learning. Ta'dib, 22(2), 131-140.

Jones, B. D., Ruff, C., Snyder, J. D., Petrich, B., \& Koonce, C. (2012). The effects of mind mapping activities on students' motivation. International Journal for the Scholarship of Teaching and Learning, 6(1). 1-21.

Karakas, B. (2015). Okul oncesi egitim alan 60-72 aylık cocuklarda "okula hairlik egitimi"nin ilkokula hairrbulunusluk duzeylerine etkisinin incelenmesi, (Yayinlanmamis Yuksek Lisans Tezi). Ege Universitesi Sosyal Bilimleri Enstitusu, Izmir.

Karolina, K. (2019). The effectiveness of mind mapping technique in enhancing students'reading achievement. Lingua Didaktika: Jurnal Bahasa dan Pembelajaran Bahasa, 13(1), 60-65. http://dx.doi.org/10.24036/ld.v13i1.36633

Khatimah, K., \& Rachman, D. (2018). Mind mapping vs semantic mapping: which technique gives EFL learners more benefits in reading comprehension? JEES (Journal of English Educators Society), 3(2), 165-176. https://doi.org/10.21070/jees.v3i2.1498

Kokkalia, G., Drigas, A. S., Economou, A., \& Roussos, P. (2019). School readiness from kindergarten to primary school. International Journal of Emerging Technologies in Learning (iJET), 14(11), 4-18. https://doi.org/10.3991/ijet.v14i11.10090

Koster, M.,van der Wilt, F., van Kruistum, C., van der Veen, C. (2017). The effect of mindmapping on listening comprehension and vocabulary in early childhood education. Paper presenten at In European Association for Research on Learning and Instruction.

Kybartas, T.J., Oody, J.F. Fairbrother, J.T., Durham, R.S. \& Coe, D.P. (2019): Physical activity intensity, self-regulation, and school readiness indicators in young children, Early Child Development and Care, 191(1), 501-510. https://doi.org/10.1080/03004430.2019.1625896

Landry, S.H., Zucker, T.A., Williams, J.M., Merz, E.C. Guttentag, C.L. \& Taylor, H.B. (2017) Improving school readiness of high-risk preschoolers: Combining high quality instructional strategies with responsive training for teachers and parents, Early Childhood Research Quarterly 40, 38-51. https://doi.org/10.1016/j.ecresq.2016.12.001 
Lara-Cinisomo, S., Fuligni, A. S., Ritchie, S. (2008). Getting ready for school: An examination of early childhood educators' belief systems. Early Childhood Education Journal, 35(4),343-349. https://doi.org/ 10.1007/s10643-007-0215-2

Lastari, N. K. H., \& Hadi, P. R. T. A. K. (2018). The use of mind mapping to improve writing skill of the eighth grade students of junior high school. Journal of Applied Studies in Language, 2(2), 144-150.

Lemelin, J. P., Boivin, M., Forget-Dubois, N., Dionne, G., Seguin, J. R., Brendgen, M., Vitaro, F., Tremblay, R. E., \& Pe'russe, D. (2007). The genetic - environmental etiology of cognitive school readiness and later academic achievement in early childhood. Child Development, 78 (6), 1855-1869. https://doi.org/10.1111/j.1467-8624.2007.01103.x

Liu, Y., Zhao, G., Ma, G., \&Bo, Y. (2014). The effect of mind mapping on teaching and learning: a meta-analysis. Standard Journal of Education and Essay, 2(1), 17-31. ISSN: 2310-7545

Lonigan, C.J., Phillips, B.M., Clancy, J.,L., Landry, S.H., Swank, P.R., Assel, M. et al. (2015). Impacts of comprehensive school readiness curriculum for preschool children at risk for educational difficulties, Child Development, 86 (6). 1773-1793. https://doi.org/10.1111/cdev.12460

Luke, H., Lloyd, D., Boyd, W., \& Den Exter, K. (2014). Improving conservation community group effectiveness using mind mapping and action research. Conservation and Society, 12(1), 43-53.

Mardiyah, I., Suhito, S., \& Safa'atullah, M. F. (2018). Analysis of mathematical reasoning ability of junior high school students of grade VII viewed from cognitive style on problem based learning with mind mapping. Unnes Journal of Mathematics Education, 7(2), 122128. https://doi.org/10.15294/ujme.v7i2.24883

Mathis, E.T.B. \&Bierman, K.L. (2015). Effects of parent and child pre-intervention characteristics on child skill acquisition during a schoolreadiness intervention. Early Childhood Research Quarterly 33, 87-97. https://doi.org/10.1016/j.ecresq.2015.07.002

McKillup, S. (2012). Statistics explained: An introductory guide for life scientists (Second edition). Cambridge University Press.

Mercan-Uzun, E., \& Alat, K. (2015). Okul oncesi donemde uygulanan "okula haziriz" egitim programinin ilkokul birinci sınıf ogrencilerinin okula uyum ve hairrbulunusluk duzeylerine etkisi (Yayinlanmamıs Doktora Tezi). Ondokuz Mayis Universitesi Egitim Bilimleri Enstitusu, Samsun.

Nesbit, J. C., \& Adesope, O. O. (2006). Learning with concept and knowledge maps: Ametaanalysis. Review of Educational Research, 76(3), 413-448. https://doi.org/10.3102\%2F00346543076003413

Ozsari, E. (2017). Oykulestirme yontemine dayali egitimin bes yas grubundaki cocuklarin ilkogretime hazir bulunusluk seviyelerine etkisinin incelenmesi, (Yayinlanmamis Yuksek Lisans Tezi). Canakkale Onsekiz Mart Universitesi Egitim Bilimleri Enstitusu, Canakkale.

Padilla, C. M., \& Ryan, R.M. (2018). School readiness among children of Hispanic immigrants and their peers: The role of parental cognitive stimulation and early care and education. Early Childhood Research Quarterly 52 (3), 154-168.

kttp://doi.org/10.1016/j.ecresq.2018.04.008

Parikh, N. D. (2016). Effectiveness of teaching through mind mapping technique. The International Journal of Indian Psychology, 3(3), 148-156.

Pears, K. C., Healey, C. V., Fisher, P. A., Braun, D., Gill, C., Conte, H. M., ... \& Ticer, S. (2014). Immediate effects of a program to promote school readiness in low-income children: Results of a pilot study. Education \& Treatment of Children, 37(3), 431.https://doi.org/ 10.1353/etc.2014.0021

Pratami, D., Puspita, I. A., \& Hadining, A. F. (2017). The effect of "mindmap" knowledge codification Implementation and motivation to Individual achievement. Advanced Science Letters, 23(5), 4110-4114. https://doi.org/10.1166/asl.2017.8255 
Prendergast, S. \& MacPhee, D. (2018). Parental contributors to children's persistence and school readiness, Early Childhood Research Quarterly, 45, 31-44.

https://doi.org/10.1016/j.ecresq.2018.05.005

Rustler, F. (2012). Mind mapping for dummies. John Wiley \& Sons.

Schmitt, S.A., McClelland, M.M., Tominey, S.L. \& Acock, A.C. (2015). Strengthening schoolreadiness for Head Start children: Evaluation of a self-regulation intervention, Early Childhood Research Quarterly 30, 20-31. https://doi.org/10.1016/j.ecresq.2014.08.001

Sonmez, A. (2013). 60-72 aylik dezavantajlı cocuklar icin hazirlanan ilkogretime hazirlik oyun destek programının cocuklarin ilkogretime hazirbulunusluk duzeyine etkisi, (Yayinlanmamis Yuksek Lisans Tezi). Marmara Universitesi Egitim Bilimleri Enstitusu, Istanbul.

Sugiyanto, F. N., Masykuri, M., \& Muzzazinah, M. (2018). Feasibility of resiratory system module based on creative problem solvıng learnıng model with mind mapping to empower problem solving skills. EDUSAINS, 10(2), 275-281. https://doi.org/10.15408/es.v10i2.8054

Sukma, D. E., \& Ria, G. (2018). The use of mind mapping picture to improve students'writing skill of descriptive text at grade VIII of smp s johan sentosa. AL-ISHLAH: Jurnal Pendidikan, 10 (2), 188-197.

Thalheimer, W., Cook, S. (2002). How to calculate effect sizes from published research: A simplified methodology. Work-Learning Research, 1, 1-9.

Toran, M., Aydin, E., \& Etguer, D. (2019). Investigating the effects of STEM enriched implementations on school readiness and concept acquisition of children. Elementary Education Online, 19(1), 299-309. https://doi.rg/ 10.17051/ilkonline.2020.656873

Uzun, E. M. (2015). Okul oncesi donemde uygulanan 'okula haziriz' egitim programinin ilkokul birinci sinif ogrencilerinin okula uyum ve hazırbulunusluk duzeylerine etkisi. Yayinlanmamıs Doktora Tezi, Ondokuz Mayis Universitesi Egitim Bilimleri Enstitusu, Samsun.

Watts, T. W., Gandhi, J., Ibrahim, D. A., Masucci, M. D., \& Raver, C. C. (2018). The Chicago School Readiness Project: examining the long-term impacts of an early childhood intervention. PloS one, 13(7). 1-25. https://doi.org/10.1371/journal.pone.0200144

Wen-Cheng, W., Chung-Chieh, L., \& Ying-Chien, C. (2010). A brief review on developing creative thinking in young children by mind mapping. International Business Research, 3(3), 233238.

West, J.,Denton, K., Germino Hausken. (2000). America's kindergartners: findings from the early childhood longitudinal study, kindergarten class of 1998-99 national center for education statistics. U.S. Department of Education: Washington.

Widiana, I. W., \& Jampel, I. N. (2016). Improving students' creative thinking and achievement through the implementation of multiple intelligence approach with mind mapping. International Journal of Evaluation and Research in Education, 5(3), 246-254.

Wolf, S. \& McCoy, D.C. (2019). Household socioeconomic status and parental investments: direct and indirect relations with school readiness in Ghana, Child Development, 90 (1), 260-278 https://doi.org/10.1111/cdev.12899

Yildirim, C. (2019). Montessori yontemine dayali ogretim tasarımının birinci sinif ogrencilerinin hazırbulunusluklarina matematik ve okuma-yazma becerilerine etkisi. (Yayinlanmamis Doktora Tezi), Burdur Mehmet Akif Ersoy Universitesi Egitim Bilimleri Enstitusu, Burdur.

Zigler, E., Gilliam, W. S., Jones S.M. (2006). A vision for universal preschool education. Cambridge University Press. 


\section{Biographical notes:}

Özgül Polat received B.S. and M.A. degrees in Preschool Education from Marmara University. She completed her Ph.D. studies in the Preschool Education Program of Marmara University in 2003. Her thesis was about school readiness and she developed the "Marmara Primary School Readiness Scale". She participated in preschool curriculum development studies of the Republic of Turkey Ministry of National Education in 2002. Currently, she is working as an associate professor at Marmara University, where she serves since 1996. Her major research interests are in capacity building, school readiness, early childhood education programs, parent education, and multiple intelligences. She has authored or co-authored a lot of scientific publications, books, and, she has conducted many national and international projects.

Nevra Atış Akyol received B.S degrees in Preschool Education from Cumhuriyet University and M.A. degrees at Marmara University. She worked as a teacher at the Ministry of National Education between 2011 and 2015. She spent one year between 2013-2014 in the United States, and during this period, she worked as a volunteer teacher in three different schools, one of which was Headstart school. In 2015, she started her career in Cumhuriyet University Preschool Education Department. She completed her Ph.D. degrees in Preschool Education from Hacettepe University. In addition, the author worked as a visiting researcher at Roehampton University in London for 6 months in 2019-2020. Her major research interests are school readiness, emotional and social development, peer relations, mis behaviors, gender, sexual development, and family involvement. She has authored or co-authored a lot of scientific publications, books, and, she has conducted many national and international projects. 